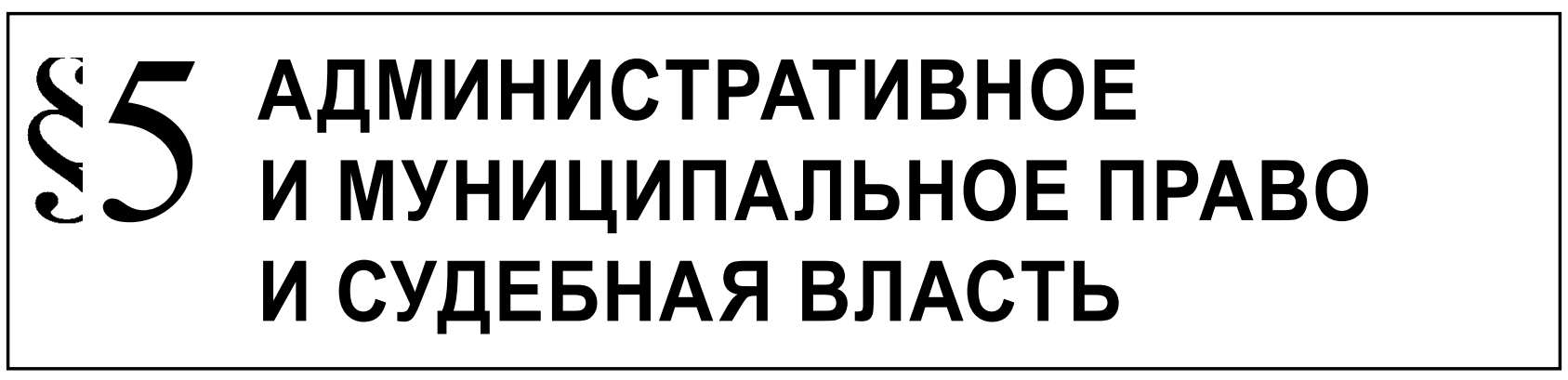

Мильчакова О.В.

\title{
РАЗРЕШЕНИЕ ЮРИСДИКЦИОННЫХ СПОРОВ (СПОРОВ О КОМПЕТЕНЦИИ) В КОНСТИТУЦИОННОМ СУДЕ
}

\begin{abstract}
Аннотация: Принципы разделения властей и территориального устройства государства неизбежно порождают споры о компетенции (юрисдикционные споры) как между различными органами центральной власти, так и между ними и органами территориальных единии, а также споры последних друг с другом. В статье уделено внимание особенностям содержания понятия «конституционно-правовых споров (споров о компетенции)» и специфике их рассмотрения конституционным судом. В качестве основы исследования используются российское и зарубежное законодательство, а также опыт конституционных судов в странах, образованных на территории бывшей Югославии (Босния и Гериеговина, Македония, Сербия, Словения, Хорватия и Черногория). Для проведения исследования автором в основном применяются формально-юридический метод, в сочетании со сравнительно-правовым методом. На основе анализа зарубежного законодательства и практики конституционных судов стран бывшей Югославии обосновывается классификация юрисдикционных споров на горизонтальные и вертикальные, негативные и позитивные. При этом подчеркивается, что одним из обязательных признаков существования спора о компетенции является принятие двумя или более органами публичной власти своих окончательных актов, которыми признается либо отрицается компетенция по одному и тому же вопросу. В заключение автор приходит к выводу о том, что в государствах исследуемого региона правила о разрешении конституционным судом юрисдикционных споров являются более демократичными, по сравнению с Россией, поскольку они предоставляют возможность обратиться за разрешением спора не только одному из спорящих органов власти, но и любому лицу, которое не может реализовать свои права вследствие возникшего спора о компетенции.

Ключевые слова: Юрисдикционные споры, Споры о компетенции, Конституционный суд, Страны бывшей Югославии, Конституционное производство, Конституционный судебный процесс, Компетенция, Признание компетенции, Отрицание компетенции, Принцип разделения властей
\end{abstract}

$\Pi$ о определению профессора Ю.А. Тихомирова, компетенция - это законно установленный объем публичных дел, выполняемых уполномоченным субъектом, элементами которой являются предметы ведения как объект воздействия и полномочия как легальная мера воздействия. Возложение публичной властью компетенции на тех или иных субъектов означает установление определенных рамок, в которых должны выполняться общие публичные функции, и наделение субъектов для этого необходимыми средствами и процедурами ${ }^{1}$.

1 См.: Тихомиров Ю.А. Споры о компетенции. // Право и экономика. 2001. № 2. С. 3-4.
Принципы разделения властей и территориального устройства государства неизбежно порождают споры о компетенции (юрисдикционные споры) как между различными органами центральной власти, так и между ними и органами территориальных единиц, а также споры последних друг с другом.

Поскольку упомянутые принципы провозглашаются в конституциях (основных законах) государств, определяющих, в том числе основы их реализации, функция арбитра в юрисдикционных спорах нередко возлагается на судебные органы конституционного контроля - конституционные суды, главной задачей которых является обеспечение конституционности и законности в стране. 
При этом разрешению в конституционном суде подлежит не любой юрисдикционный спор, а только тот, который имеет конституционно-правовой характер, касается реализации принципов, установленных в конституции.

Российские специалисты в области административного и конституционного права приводят различные классификации конституционно-правовых споров о компетенции. Так, например, профессор Н.В. Витрук относил разрешение споров о компетенции к основным полномочиям конституционных судов и указывал, что по предмету и содержанию спора можно выделить четыре их разновидности:

1) о признании компетенции: в этом случае ходатайствующий орган государственной власти считает, что принятие другим органом государственной власти нормативного правового акта или совершение конкретного действия входит в компетенцию ходатайствующего органа;

2) об отрицании компетенции: ходатайствующий орган государственной власти полагает, что спорные полномочия должны осуществляться другими органами, а последние также отрицают свои полномочия. Частным случаем подобных споров является уклонение органа от издания нормативного правового акта либо совершения действия правового характера (неконституционное бездействие);

3) о присвоении полномочия: например, орган государственной власти принимает нормативный правовой акт или совершает действия, выходя за рамки собственной компетенции, то есть толкует свои права расширительно (злоупотребление правом);

4) о противоречиях и совпадениях в компетенции различных государственных органов ${ }^{2}$.

Д.А. Кобзарь в зависимости от процессуальной формы рассмотрения споров о компетенции, а также от сферы их возникновения выделяет следующие виды споров:

1) обжалование подзаконных нормативных актов на предмет их соответствия актам более высокой юридической силы (в том числе Конституции) с точки зрения установленной этими актами компетенции соответствующего органа (органов);

2 См.: Витрук Н.В. Конституционное правосудие. Судебно-конституционное право и процесс: учеб. пособие. - 3-е изд., перераб. и доп. - М.: Норма: ИНФРА-М, 2011. С. 266, 293-294.
2) собственно споры о компетенции между высшими органами государственной власти Российской Федерации, между федеральными органами и органами субъектов Российской Федерации, между федеральными органами и органами субъектов Российской Федерации, между высшими органами субъектов Российской Федерации ${ }^{3}$.

Профессор Ю.А. Тихомиров, анализируя практику российского Конституционного Суда, выделяет несколько типичных категорий рассмотренных им дел:

1) споры по поводу объема полномочий Российской Федерации и ее субъектов, когда речь шла о трактовке, подтверждении и наделении сторон полномочиями, например, по изданию собственных законов или в случае отсутствия правовых соглашений;

2) споры по поводу объема и характера полномочий высших звеньев государственной власти применительно к организации министерств и ведомств;

3) споры в связи с нарушением в уставах ряда субъектов Российской Федерации принципов разделения властей, когда ими допускалось чрезмерное расширение полномочий областных законодательных органов и ограничение прав глав администраций;

4) споры об объеме компетенции местного самоуправления, когда государственные органы субъектов Федерации устанавливали в своих законах и подзаконных актах нормы, ограничивающие самостоятельность местной власти, и ужесточали контроль за ней ${ }^{4}$.

Мы же хотим обратиться к опыту конституционных судов стран, существующих сегодня на территории бывшей Югославии (Босния и Герцеговина, Македония, Сербия, Словения, Хорватия, Черногория), анализ которого позволяет нам предложить несколько иное представление о юрисдикционных спорах конституционно-правового характера.

Прежде всего, отметим, что как и во многих странах мира, разрешению в конституционных судах государств бывшей Югославии подлежат:

1) вертикальные юрисдикционные споры - споры о компетенции, возникающие между ор-

\footnotetext{
3 См.: Кобзарь Д.А. Судебное разрешение конституционно-правовых споров о компетенции в Российской Федерации: Автореферат дисс. на соиск. уч. степ. канд. юрид. наук. M., 2005. C. 13-14.

4 См.: Тихомиров Ю.А. Указ. соч. С. 6-7.
} 
ганами публичной власти, представляющими различные ее ветви;

2) горизонтальные юрисдикционные споры споры о компетенции, возникающие между органами власти центрального уровня и органами территориальных единиц государства (органами местного самоуправления), а также между органами территориальных единиц (органов местного самоуправления).

При этом обратим внимание, что в Боснии и Герцеговине Конституционный суд рассматривает споры о компетенции, возникающие между любыми государственными органами (институтами) Боснии и Герцеговины, и здесь не оговаривается, что спорящие стороны должны относиться к различным ветвям власти. Во всех других государствах исследуемого региона законодательством прямо предусмотрено, что конституционный суд разрешает споры, возникающие между органами законодательной, исполнительной или судебной власти (Македония, Хорватия) либо между судебными и иными органами власти (Сербия, Словения, Черногория), а также между парламентом, президентом и правительством (Словения). В качестве примера действия принципа о недопустимости вынесения на рассмотрение конституционного суда спора о компетенции между различными органами государственной власти, относящихся к одной ее ветви, приведем постановление Конституционного суда Хорватии по запросу юридического лица о разрешении негативного спора о компетенции. Поводом для обращения послужили решения Постоянно действующего арбитражного суда при Хорватской экономической палате (г. Загреб) и Хозяйственного суда в г. Загреба, отказавшихся рассматривать иск заявителя о неисполнении контракта итальянской компанией в связи с отсутствием у них компетенции на рассмотрение такого иска. Конституционный суд отказал заявителю в возбуждении производства по юрисдикционному спору, ссылаясь на ст. 128 Конституции и ст. 32 Закона о Конституционном суде. При этом Суд заявил, что не правомочен разрешать как негативные, так и позитивные споры о компетенции, возникающие между судебными органами 5 .

Специфика отнесения к компетенции органа судебного конституционного контроля горизон-

Rješenje. Odbačaj za sukob nadležnosti. Broj: U-IV-670/2003. Od 28. siječnja 2004. <http://sljeme.usud.hr/usud/praksaw.nsf/ Pojmovi/C1256A25004A262AC1256E2A00498C23?OpenDocu ment $>$. (Последнее посещение - 17 декабря 2013 г.). тальных юрисдикционных споров во многом предопределяется особенностями территориального устройства государств, степени автономии их территориальных единиц. Так, в Боснии и Герцеговине Конституционный суд рассматривает споры о применении Конституции, возникающие между двумя энтитетами (субъектами федерации), или между Боснией и Герцеговиной и одним или обоими энтитетами, либо по поводу статуса округа Брчко. В Словении в Конституционном суде подлежат рассмотрению споры о компетенции, возникшие между государством и местными общинами или между самими местными общинами; в Македонии - между органами Республики и единиц местного самоуправления; в Сербии - между республиканскими органами и краевыми органами или органами единиц местного самоуправления, между краевыми органами и органами единиц местного самоуправления, между органами различных автономных краев или различных единиц местного самоуправления; в Черногории - между государственными органами и органами единиц местного самоуправления и между органами единиц местного самоуправления. В Хорватии же Конституционный суд не наделен подобной компетенцией, и если ему и подлежат рассмотрению споры о компетенции между различными органами территориальных единиц государства, то только в том случае, если они представляют различные ветви власти (законодательную, исполнительную, судебную).

Если первая из приведенных нами классификация юрисдикционных споров основана на уровне спорящих органов власти и характере выполняемых ими задач, то в зависимости от действий органов, послуживших основанием для возникновения спора, последние могут быть классифицированы на позитивные и негативные. Заметим, что именно такая терминология чаще всего используется в законодательстве стран бывшей Югославии, регламентирующем производство в конституционном суде.

Позитивный юрисдикционный спор означает признание двумя или более органами власти компетенции по одному и тому же вопросу, а негативный - отрицание такой компетенции. При этом законодательство исследуемой группы государств, а также конституционные суды на практике очень четко подходят к вопросу о том, что должно являться подтверждением наличия спора о компетенции между двумя или более органами. Обязательным условием для обращения в конституционный суд за разрешением юрисдикционного спора должно являться принятие «спорящими» 
органами своего окончательного и вступившего в силу решения, которым соответственно признается или отрицается компетенция по одному и тому же предмету. В качестве примера приведем заключение Конституционного суда Сербии по запросу (предложению) о разрешении спора о компетенции, поданного физическим лицом. Гражданка обратилась в Суд с просьбой об объявлении городской общины Врачар г. Белграда некомпетентной в вопросе принятия решения о ее выселении из принадлежащей истице двухкомнатной квартиры. По мнению заявительницы, Департамент по имущественно-правовым и жилищным вопросам местной администрации общины незаконно присвоил себе компетенцию, приняв решение о ее выселении, поскольку последнее возможно лишь на основании судебного решения, которое может вынести Третий городской суд г. Белграда. Конституционный суд, ссылаясь на ст.ст. 68-74 Закона о Конституционном суде, отказал заявительнице в возбуждении производства о разрешении юрисдикционного спора в связи с тем, что городской суд к моменту обращения истицы в Конституционный суд еще не вынес окончательного решения по иску заявительницы об оспаривании решения Департамента по имущественно-правовым и жилищным вопросам. Конституционный суд указал, что отсутствие судебного решения, которым признавалась бы компетенция суда в решении вопросов о выселении граждан из жилых помещений, не позволяет говорить о том, что в действительности между органами исполнительной и судебной власти существует спор о компетенции ${ }^{6}$.

Таким образом, в странах бывшей Югославии непосредственно к спорам о компетенции (юрисдикционным спорам) не относятся запросы об оценке конституционности и законности актов актам более высокой юридической силы, в том числе с точки зрения установленной в них компетенции органов, а также каких-либо совпадениях и противоречиях в компетенции различных государственных органов.

Свои особенности в государствах, образованных на территории бывшей Югославии, имеет и круг лиц, которым предоставляется право обращения в конституционный суд за разрешением юрисдикционного спора.

\footnotetext{
6 Закључак о одбацивању захтева за решавање сукоба надлежности. Број: IIIУ-95/2009. Од 04.02.2010. <http://www. ustavni.sud.rs/Storage/Global/Documents/Predmeti/sr-Cyrl-CS/ IIIU-95-2009.Doc>. (Последнее посещение - 17 декабря 2013 г.).
}

В Боснии и Герцеговине за разрешением спора о компетенции могут обратиться только уполномоченные представители органов государственной власти, наделенные, в том числе правом запроса об оценке конституционности и законности любых актов: член Президиума Боснии и Герцеговины (коллективного главы государства), Председатель Совета министров, Председатель или заместитель Председателя любой из палат национального парламента, члены любой из палат национального парламента в количестве не менее 1/4 ее состава, члены законодательного органа любого энтитета в количестве не менее 1/4 ее состава.

Однако во всех других рассматриваемых государствах запрос о разрешении юрисдикционного спора в конституционный суд может направить не только любой из органов, являющихся стороной конфликта, но и иное лицо, пострадавшее вследствие присвоения компетенции органом публичной власти или отказа от нее, которое не может реализовать свои права и в связи с обращением которого возник такой спор.

Производство в конституционном суде по разрешению юрисдикционного спора имеет свои особенности, по сравнению с обычной процедурой рассмотрения дел об оценке конституционности и законности актов. Прежде всего, как правило, устанавливаются предельные сроки на подачу соответствующего запроса, видимо не только для того, чтобы вопрос не потерял своей актуальности, но и для защиты прав лиц, в отношении которых органами власти принимаются решения, что особенно важно при применении уголовно-процессуального законодательства. Например, в Сербии и в Черногории запрос о разрешении юрисдикционного спора может быть подан в конституционный суд в срок не позднее 15 дней со дня признания органом власти юрисдикции либо отказа от нее, в Хорватии - не позднее 30 дней, в Словении - не позднее 90 дней.

Обязательными участниками конституционного судебного процесса в рамках разрешения юрисдикционного спора являются не менее чем два государственных органа (и/или органа местного самоуправления). При этом они могут иметь статус как заявителя (истца), так и ответчика, либо оба выступать в качестве ответчиков, если производство возбуждено на основании иска лица, который не может реализовать свои права вследствие возникшего спора о компетенции.

Как мы уже отмечали, необходимым условием возникновения и существования спора о компетенции является принятие окончательных и 
вступивших в силу актов спорящими органами участниками спора. В связи с этим одним из требований о допустимости запроса о разрешении юрисдикционного спора является принятие органами окончательных актов, которыми, по мнению заявителя, присвоена либо отрицается компетенция по определенному вопросу. Таким образом, такой запрос не может иметь абстрактный, неопределенный характер, а всегда связан с конкретными обстоятельствами и действиями органов власти.

В ходе конституционного производства по разрешению спора о компетенции конституционный суд в обязательном порядке направляет органу, в отношении которого подано заявление, это заявление для представления ответа на него и своей позиции в конституционный суд. При этом могут быть установлены весьма короткие сроки для ответа: например, в Сербии срок для ответа, предоставляемый органу, принявшему акт, являющийся предметом рассмотрения в производстве по разрешению юрисдикционного спора, составляет 8 дней (а при обычной процедуре об оценке конституционности и законности - 15 дней).

Во всех исследуемых странах у конституционных судов есть возможность в случае необходимости запретить исполнение актов, являющихся предметом рассмотрения в производстве по разрешению спора о компетенции, до вынесения своего решения по существу спора.

Итогом рассмотрения юрисдикционного спора в конституционном суде является определение конкретного органа, который является компетентным в принятии решения по вопросу, в связи с которым возник спор о компетенции.
Если провести сравнение компетенции конституционных судов по разрешению споров о компетенции в странах бывшей Югославии, к примеру, с Россией, то необходимо отметить, что здесь присутствует определенное сходство. Так, исходя из ст. 3 Федерального конституционного закона от 21.07.1994 № 1-ФКЗ «О Конституционном Суде Российской Федерации» ${ }^{7}$, Конституционный Суд разрешает как вертикальные споры о компетенции, так и горизонтальные, позитивные и негативные. Ему подведомственны споры о признании или отрицании компетенции, возникающие между: федеральными органами государственной власти; органами государственной власти Российской Федерации и органами государственной власти субъектов Российской Федерации; высшими государственными органами субъектов Российской Федерации.

В отличие от большинства стран бывшей Югославии (за исключением Боснии и Герцеговины), правом запроса российского Конституционного суда о разрешении юрисдикционного спора обладают только уполномоченные органы власти (любой из участвующих в споре органов государственной власти, в отдельных случаях - и Президент). Вместе с тем учитывая, что на органы государственной власти не возлагается обязанность обращаться в конституционный суд за разрешением юрисдикционного спора, предоставление гражданам, права которых нарушены или не могут быть реализованы вследствие такого спора, возможности обратиться в конституционный суд за его разрешением, представляется весьма демократичным, позволяющим обеспечить полноценную защиту прав и свобод человека и гражданина.

\section{Библиография:}

1. Бондарь Н. С. Судебный конституционализм в России в свете конституционного правосудия. М., 2011.-544 с.

2. ВитрукН.В.Конституционноеправосудие.Судебно-конституционноеправо ипроцесс:учеб. пособие.3-е изд., перераб. и доп. М., 2011.-592 с.

3. Клишас А. А. Конституционный контроль и конституционное правосудие зарубежных стран. Сравнительно-правовое исследование / Под ред. В. В. Еремяна. М., 2007.-496 с.

4. Кобзарь Д. А. Судебное разрешение конституционно-правовых споров о компетенции в Российской Федерации: Автореферат дисс. на соиск. уч. степ. канд. юрид. наук. М., 2005.-22 с.

\footnotetext{
Федеральный конституционный закон от 21 июля 1994 г. № 1-ФКЗ «О Конституционном Суде Российской Федерации» // Собрание законодательства РФ. 1994. № 13. Ст. 1447; 2001. № 7. Ст. 607; 2001. № 51. Ст. 4824; 2004. № 24. Ст. 2334; 2005. № 15. Ст. 1273; 2007. № 7. Ст. 829; 2009. № 23. Ст. 2754; 2010. № 45. Ст. 5742; 2011. № 1. Ст. 1; 2012. № 53 (ч. 1). Ст. 7572; 2013. № 14. Ст. 1637.
} 
5. Конституционный контроль в зарубежных странах: учеб. пособие / отв. ред. В. В. Маклаков. - 2-е изд., испр. и доп. М., 2010.-672 с.

6. Кутафин О. Е., Фадеев В. И. Муниципальное право Российской Федерации. М., 2011.-672 с.

7. Нуриев Г. Х. Европейская модель конституционного судопроизводства. М., 2012.-224 с.

8. Несмеянова С. Э. Конституционный судебный процесс в России: Учеб. пособие. М., 2012.-204 с.

9. Тихомиров Ю. А. Споры о компетенции. // Право и экономика. 2001. № 2. С. 3-7.

10. О. А. Кожевников Некоторые проблемы в разграничении подведомственности споров между судами общей юрисдикции и конституционными (уставными) судами субъектов РФ и пути их разрешения // Право и политика. - 2012. - 5. - С. 897 - 901.

11. С.В. Нарутто Конституционный судебный процесс: понятие, признаки, особенности // Право и политика. - 2013. - 5. - С. 708 - 713. DOI: 10.7256/1811-9018.2013.05.15.

12. Стародубцева И.А. Конституционные основы предотвращения и разрешения коллизий в России и зарубежных странах: сравнительно-правовое исследование // Журнал зарубежного законодательства и сравнительного правоведения. - 2012. - 6. - С. $23-29$.

13. С. В. Нарутто Принцип конституционности разграничения компетенции между органами государственной власти Российской Федерации и ее субъектов в судебной практике // Право и политика. 2012. - 9. - С. $1471-1478$.

\section{References (transliterated):}

1. Bondar' N. S. Sudebnyi konstitutsionalizm v Rossii v svete konstitutsionnogo pravosudiya. M., 2011.-544 s.

2. Vitruk N. V. Konstitutsionnoe pravosudie. Sudebno-konstitutsionnoe pravo i protsess: ucheb. posobie. - 3-e izd., pererab. i dop. M., 2011.-592 s.

3. Klishas A. A. Konstitutsionnyi kontrol' i konstitutsionnoe pravosudie zarubezhnykh stran. Sravnitel'nopravovoe issledovanie / Pod red. V. V. Eremyana. M., 2007.-496 s.

4. Kobzar' D. A. Sudebnoe razreshenie konstitutsionno-pravovykh sporov o kompetentsii v Rossiiskoi Federatsii: Avtoreferat diss. na soisk. uch. step. kand. yurid. nauk. M., 2005.-22 c.

5. Konstitutsionnyi kontrol' v zarubezhnykh stranakh: ucheb. posobie / otv. red. V. V. Maklakov. — 2-e izd., ispr. i dop. M., 2010.-672 s.

6. Kutafin O. E., Fadeev V. I. Munitsipal'noe pravo Rossiiskoi Federatsii. M., 2011.-672 s.

7. Nuriev G. Kh. Evropeiskaya model' konstitutsionnogo sudoproizvodstva. M., 2012.-224 s.

8. Nesmeyanova S. E. Konstitutsionnyi sudebnyi protsess v Rossii: Ucheb. posobie. M., 2012.-204 s.

9. Tikhomirov Yu. A. Spory o kompetentsii. // Pravo i ekonomika. 2001. № 2. S. 3-7.

10. 0. A. Kozhevnikov Nekotorye problemy $\mathrm{v}$ razgranichenii podvedomstvennosti sporov mezhdu sudami obshchei yurisdiktsii i konstitutsionnymi (ustavnymi) sudami sub"ektov RF i puti ikh razresheniya // Pravo i politika. - 2012. - 5. - C. 897 - 901.

11. S.V. Narutto Konstitutsionnyi sudebnyi protsess: ponyatie, priznaki, osobennosti // Pravo i politika. — 2013. — 5. - C. 708 - 713. DOI: 10.7256/1811-9018.2013.05.15.

12. Starodubtseva I.A. Konstitutsionnye osnovy predotvrashcheniya i razresheniya kollizii v Rossii i zarubezhnykh stranakh: sravnitel'no-pravovoe issledovanie // Zhurnal zarubezhnogo zakonodatel'stva i sravnitel'nogo pravovedeniya. - 2012. - 6. - C. $23-29$.

13. S. V. Narutto Printsip konstitutsionnosti razgranicheniya kompetentsii mezhdu organami gosudarstvennoi vlasti Rossiiskoi Federatsii i ee sub" ektov v sudebnoi praktike // Pravo i politika. - 2012. - 9. — C. 1471 - 1478. 